\title{
DO DOCTORS NEED COMMUNICATION IN THEIR JOB PLACES? (A CASE IN INDONESIA)
}

\author{
Dwi Poedjiastutie, Ratih Puspitasari \\ University of Muhammadiyah Malang, Indonesia
}

(dpoedjiastutie@yahoo.com)

Received: $18^{\text {th }}$ September 2018; Revised: $25^{\text {th }}$ November 2018; Accepted: $28^{\text {th }}$ Desember 2018

\begin{abstract}
The current study revealed the communication needs of medical students at Universitas Muhammadiyah Malang (UMM). Three approaches of Need Analysis (NA) were combined in this study; Target Situation Analysis (TSA), Presentation Situation Analysis (PSA), and Pedagogical Need Analysis (PNA). The questionnaires were circulated to medical students. The findings discovered that communication skill was considered important in EMP course. The medical students realized the importance of doctors' communication in order to enhance better performance in their professional settings. ESP teachers are supposed to give a model of communication; Students also expected that the materials should be authentic. The materials design should have clear and coherent objectives to help the students achieving the communication goals. Moreover, students want ESP teaching put them as close as possible to the workplace situation.
\end{abstract}

Keywords: needs analysis; english for medical purposes; communication needs; authentic classroom activities

\begin{abstract}
ABSTRAK
Penelitian ini bertujuan untuk mengidentifikasi kebutuhan materi pembelajaran Bahasa Inggris komunikasi pada mahasiswa kedokteran di Universitas Muhammadiyah Malang. Pendekatan yang digunakan dalam penelitian ini adalah gabungan antara Target Situation Analysis (TSA), Presentation Situation Analysis (PSA), dan Pedagogical Need Analysis (PNA). Dari data yang diperoleh dalam penelitian ini ditemukan bahwa mahasiwa kedokteran merasa mata kuliah EMP (English for Medical Purposes) itu penting untuk menunjang karir dan profesi mereka. Maka dari itu para pengajar mata kuliah ESP (English for Specific Purposes) diharapkan bisa memberikan model-model materi pengajaran Bahasa Inggris untuk komunikasi yang otentik; yaitu materi yang tepat untuk mengasah ketrampilan mereka dalam komunikasi. Bahkan, para mahasiswa kedokteran menginginkan adanya model-model pengajaran ESP yang bisa membawa mereka ke situasi semirip mungkin dengan dunia kerja mereka di kemudian hari.
\end{abstract}

Kata kunci: analisa kebutuhan; Bahasa Inggris untuk kedokteran; kebutuhan materi pengajaran komunikasi yang autentik

How to Cite: Poedjiastutie, D., Puspitasari, R. (2018). Do Doctors Need Communication in Their Job Places? (A Case in Indonesia). IJEE (Indonesian Journal of English Education), 5(2), 127-142. doi:10.15408/ijee.v5i2.10134

IJEE (Indonesian Journal of English Education), 5 (2), 2018, 127-142

P-ISSN: 2356-1777, E-ISSN: 2443-0390 | DOI: http://dx.doi.org/10.15408/ijee.v5i2.10134

This is an open access article under CC-BY-SA license (https://creativecommons.org/licenses/by-sa/4.0/) 


\section{INTRODUCTION}

Communication skill is the most demanded by the employers to increase their productivity in their workplaces. Morreale \& Pearson (2008) argues that a person can represent him/herself in professional settings through good communication. This phenomena in language learning is triggered by the situation where nowadays countries cannot not stand alone in fulfilling their own human resources for some reasons.For example, due to the shortage of human resources South East Asia (ASEAN) has established Mutual Recognition Arrangement (MRA) focusing in Eight professional services. The agreement facilitates mobility in professional or skilled labor in engineering; nursing; architectural; mutual recognition of surveying qualifications; medical and dental practitioners; accountancy; and tourism services. This agreement is expected to enhance cooperation amongst ASEAN countries. As mentioned earlier.one of the professional sectors targeted for mobility is medical practitioners (MP). This is because the distribution of medical practitioners in some ASEAN region is still disproportionate (Arunanondchai \& Fink, 2006; Supakankunti \& Herberholz, 2012). However, ASEAN currently does not have one standard medical qualificationcompetence and curriculum. Consequently, with a variety of standards and skills, accordingly limit the mobility of doctors around ASEAN countries.

One of the skills required for mobility according to MRA is having a good command of English.The medical study has come into prominence which English is used as the primary means of communication in correspondences, conferences, and in the process of writing scientific articles (Antic, 2007; Milosavljević, Vuletić, \& Jovković, 2015; and Pavel, 2014). As a result, providing English for Medical Purposes (EMP) for the future doctors come into considerations in several medical and healthcare institutions around the globe. For example, nowadays in Saudi Arabia and other Middle East countries, the medical universities include EMP as the part of their curriculum. The students have to complete EMP courses in their first year academic (Arani, 2014; Fahad \& Alfehaid, 2011; Faraj, 2015; and Ibrahim, 2016). In similar vein, the Ministry of Public Health in Cuba takes full responsibility for all medical education, including English for medical undergraduates and postgraduates. The students need to take five years language course in total; three years of learning General English courses and 2 years of learning medical components (Maclean, Betancourt, \& Hunter, 2000).

In China, several universities establish international classes for medical students. Medical Council in New Zealand designs EMP for overseas student doctors come from South East 
Asia, the Middle East, and Eastern Europe. In this 'bridging program' English is taught as the part of doctor professional development (Basturkmen, 2010).

\section{The Context of the Study}

Preparing medical students with EMP has also been done by University Muhammadiyah Malang (UMM) of Indonesia. The Medical Faculty UMM provides students with English subjectsintensively in their first year of study. The Faculty cooperates withLanguage Center (LC)as the unit that takes in charge of the English for Specific Purposes (ESP) program. ESPat this university is offered to all freshmen enrolled at 38 Departments at UMM, including Medical School. This program offers six credits in the first semester which cover Intermediate ESP Reading ( 2 credits), Intermediate ESP Speaking (2 credits), and Intermediate ESP Listening course ( 2 credits). Then, in the second semester, the students are still obliged to take another six credits learnings: Advanced Reading (2 credits), Advanced Speaking (2 credits), and Advanced Writing course (2 credits). The purpose is to improve the students' English proficiency and prepare them for future careers.

So'ud (2016) have found that the mismatch between students' needs and the course implementation led to graduates' and employers' disappointment. This is in line with
Long (2005) who argues that a one-size-fits-all approach does not make sense for ESP course since learners have diverse needs in every domain.

From the preliminary observation, several issues were found. The English materials for medical students (EMP) focused more on General English and did not reflect on what doctor usually communicate for. As a result, the speaking materials were not relevant for medical students. Furthermore, the teacher spent much time giving explanation and focusing on grammar. Another issue, the number of students was too big (58 students) for communication. Consequently, students have little opportunity to practice communication. This is exacerbated by the absence of systematic needs analysis (NA) study. This practice is contradictive to what literature elsewhere recommended. For example, Richards (2001) claims that the aims of the ESP program should meet the specific needs of particular group of learners.

Needs analysis (NA) is the approach to obtain valuable data to develop curricula fit with the learners' expectations (Grier, 2005; Hutchinson \& Waters, 1987; Long, 2005; Poedjiastutie \& Oliver, 2017). The data about the learners' needs can be a critical step to develop the appropriate syllabus and course design. In addition, the results of NA can be used as decision making on the course intensity, the course duration, the syllabus content, the teaching and 
learning materials, and the teaching methodologies (Richards, 2001). There are three different NA approaches Target Situation Analysis (TSA), Present Situation Analysis (PSA), and Pedagogical Needs Analysis (PNA)

\section{Target Situation Analysis (TSA)}

Robinson (1991) suggested TSA as "What did students need to be able to do" in English as a result of the course?" (p. 196). TSA was originally devised by Munby (1978). He introduced Communicative Needs Processor (CNP). CNP focused on the students' needs in the end of the language course and target level performance. Munby (1978)proposed eight parameters which are considered as the variables in deciding learners' communication needs. The parameters are purposive domains, setting, interaction, instrumentality, dialect, communicative event, communicative key, and target level.

Following the CNP model, Hutchinson \& Waters (1987) also proposed TSA which focused on the target situation and the language learners' attitudes towards the situations. They distinguished between target needs and learning needs. Target needs deal with what the learner needs to do in the target situation. In identifying the target needs, the researchers have to be able to differentiate lacks, necessities, and wants. Lacks refer to the gap between the existing proficiency by the learners and the target proficiency. Necessities refer to types of needs which are determined by the demands of the target situation. Wants refer to what the learners want to learn. On the other hand, learning needs deal with what the learner needs to do in order to learn. The typical questions asked for these needs are (a) Why language is used? (b) How will the language be used? (c) What will the content areas be? (d) Where will the language be used? and (e) When will the language be used?

For example, Atai \& Nazari (2011) and Noori \& Mazdayasna(2014) conducted NA using TSA approach in order to investigate the lack, necessities, and wants of Iranian undergraduate students. The result of these studies drew attention of the students' needs that should have been taken into consideration by the institution in order to improve the students' communication skills.

\section{Present Situation Analysis (PSA)}

PSA was proposed by Richterich and Chancerel (1980). The information is obtained from the students, the language teaching establishment, and the user institution. The data was collected by administering surveys, questionnaires, and interviews. The researchers are recommended to seek information regarding the students' perceived ability in learning English and the students' views on language 
teaching and learning. In addition, Dudley-Evans \& John (1998) and Robinson (1991) recommended to put society and culture into the consideration when analyzing the data. It includes the students' attitude towards the use of a foreign language.

\section{Pedagogical Need Analysis (PNA)}

As cited in Songhori (2008), West proposed the pedagogical needs analysis as the umbrella of three kinds of needs analysis. They are Deficiency Needs Analysis, Strategy Analysis, and Means Analysis. Deficiency Analysis refer to Hutchinson \& Waters(1987)'s explanation regarding lacks. The syllabus may be developed by collecting the students' gap between the existing proficiency and target proficiency. Meanwhile, the pioneer of Strategy Needs Analysis was West(1994). This approach focuses on the students' perception of their needs in their own terms. It is derived from the needs, lacks, and wants which was introduced by Allwright (1982) and Hutchinson \& Waters(1987). They agreed that this approach will identify the skill area and the students' preferred learning strategies. Means Analysis was proposed by Holliday and Cooke (1982)which emphasize on the context of learning, such as the teachers, teaching methodologies, students, and facilities.

In order to examine the medical students' learning needs and their target needs, this study combined three approaches of NA: TSA, PSA, and PNA; as described in the Figure 1. TSA approach draws the target situation needs expected by the medical students in learning English. Meanwhile, PSA investigates the medical students' present level of English whether they are in elementary, intermediate or advanced level of English. The students' present level of English (PSA) is used to inform the researcher how far the medical students need to spend their time studying English in order to achieve the target situation. The purpose of the questionnaire is to students' perceptions on determining their own needs (PNA). The diagram below describes how the three NA approaches is combined. The diagram below describes how the three NA approaches is combined.

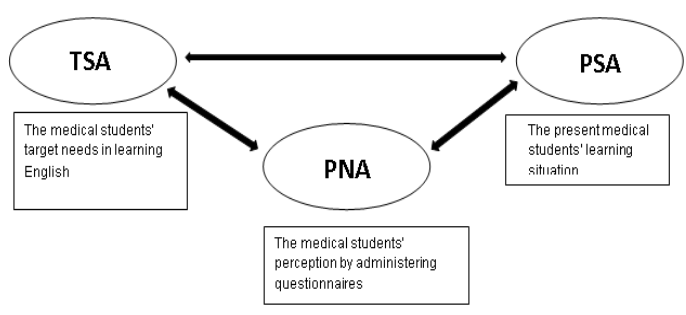

Figure 1. TSA, PSA, and PNA were implemented in this study

Abundant researches have been conducted in relation to communication needsat the differentworkplace settings. For example, the English courses for engineers should have been constructed based on the employer's daily basis communication which also include technical English terminologies (Ghenghesh, 2013; Gözüyeşil, 2014; 
Habbash \& Albakrawi, 2014; Kim, 2013; \& Polyakova, 2015 ); English for tourism and hospitality industry (Albakrawi, 2013; Lin, Wu, \& Huang, 2013; Prachanant, 2012); business English (Jeczelewski, 2016; Juan, 2014; Zhang \& Wang, 2015,); telecommunication services (Unueshotse, (2017); economic science and technology (Farida \& Asmaa, 2017); and computer science (Ho, 2014).

However, a few studies reveal the importance of communication for doctors' professional growth. For example, one study conducted by Mubaraq (2017) just recently examine the students' English needs in two different institutions. The result showed that the medical students were unsatisfied with the current EMP program due to unclear syllabus and materials.

Therefore, this study is intended to examine UMM students' needs of EMP. This study is significant in that it integrates several different approaches to NA research for English language programs, and it seeks to do this in a country where such approaches have rarely hitherto been attempted. It has been carried out at a time when increasing importance is being attached to professionally-conducted NA as educators respond to theory changes and research findings in Second Language Acquisition (SLA) and the emergence of analytic Second Language (L2) syllabus design.

\section{METHOD}

This study is quantitative in nature and a survey research design is employed. This is the procedures in quantitative research in which the researchers administer survey to a sample or to entire population to describe attitude, opinion, behavior, or characteristic of population (Creswell, 2015). He further asserts that there are two basic types of survey research: Cross-Sectional and Longitudinal design. Cross-Sectional design was employed in this study. In Cross-Sectional design, the researcher collects data at one point in time. Cross-Sectional study can examine current attitudes, beliefs, opinions, or practices. Attitudes, beliefs, and attitudes are ways in which individual thinks about issues, whereas practices are their actual behavior (Ary, Jacobs, Razavieh, \&Sorensen, 2006).

Cresswell (2015) also demonstrates that Cross-Sectional survey can measure community needs of educational services as they relate to the programs and courses. Since this study is looking for the answer of the UMM medical students' needs of learning English, a cross-sectional survey was used in this study.

Closed-ended questionnaire were constructed based on the information that the researcher wanted to reveal from the students. Therefore, a group of people consisting of six (three 
researchers and threemedical students were involved to formulate the questionnaire items.

There were four questions items of questionnaireswhich is important to reveal medical students' needs of EMP. Then, the questionnaires were circulated to bigger number of students. 125 out of 300 students of Medical Faculty of UMM were willing to participate in survey. There were 74 male students and 51 female students. Twenty out of 125 were alumni and 105 of the respondents were students who are still studying at Medical Faculty. At the time of data collection, most respondents were in the intermediate level of English because they had learnt English inhigh schools and had attended English courses fromone to two years. Their age range were around 18 to 19 years old. Almost all of them came from various part of Java, while only few of them came from outside of Java.

One concern that should be taken into consideration was the issue of reliability and validity. Reliability is the central concept in measurement and it basically means consistency. As Punch (1998) states that if the same instrument were given to the same people, under the same circumstances but at different time, the extent to which they would get the same score, the measuring instrument is reliable.

The second central concept of the measurement is validity. Validity means the extent to which an instrument measures what is claimed to measure. Punch (1998) argues that there is no foolproof procedure to establish validity. He further asserts that a valid inference occurs when there is no conflict between messages received as a result of the use a variety of different methodological procedures.

Each subject completed questionnaire individually at his or her own convenience. Names and addresses were not required on the questionnaires in order to encourage the respondents to give sincere answers. However, they were asked to give personal information only such as: age, sex, and the academic year of the students' entrance. A plain language statement was also posted out together with the questionnaire. The low response rate may occur when the survey had to be conducted by mail since the researcher did not have any control over data collection in that situation.

Data from questionnaire are analyzed using simple descriptive statistics using percentage. Dörnyei (2002) states that questionnaire was employed in order to obtain opinions from large number of respondents. This information is needed for policy makers especially the Dean of Medical Faculty to make quick decisions of regarding to the future's syllabus deign. 


\section{FINDINGS AND DISCUSSION}

\section{English Skill Priority}

The first question was intended to reveal English skill needed by the medical students. Sixty-three or $50.4 \%$ considered speaking or communication the first skill they need to master. It showed that the students' priority of English learning is to be able to speak or to communicate. Reading was on the second highest with 33 students or $26.4 \%$. Writing skill was the last skill that medical students were expected to master with the total number of 11 respondents or $8.8 \%$. The summary of the English skills needed by medical students can be seen in Table 1 .

Table 1. English skills priority

\begin{tabular}{|c|c|c|}
\hline $\begin{array}{l}\text { English skill } \\
\text { Rank }\end{array}$ & $\begin{array}{l}\text { Number of } \\
\text { students }\end{array}$ & Percentage (\%) \\
\hline Speaking & 63 & 50.4 \\
\hline Reading & 33 & 26.4 \\
\hline Listening & 18 & 14.4 \\
\hline Writing & 11 & 8.8 \\
\hline $\begin{array}{l}\text { Total of the } \\
\text { students }\end{array}$ & 125 & 100 \\
\hline
\end{tabular}

\section{The Purpose of English Learning}

Number two of the questionnaires was intended to disclose the purpose of the students learning English. The result showedthat most of the respondents learn English not only to enhance their professional skills, but also, they want to improve their interpersonal skills to communicate in English. The highest number showed that 21 students or $16.8 \%$ chose they learn English in order to become successful medical professional. Secondly, eighteen students or $14.4 \%$ learnt English in order toenhance their academic performance. Additionally, the results also showed that 16 students wanted to learn English because they want to travel abroad (1.8\%). Surprisingly, a few students (9 students or $4.8 \%$ ) learnt English for scholarship or overseas trainings. Table 2 below summarized the medical students' goal of English learning.

Table 2. The purpose of English learning

\begin{tabular}{|c|c|c|}
\hline Items & $\begin{array}{l}\text { Number } \\
\text { of } \\
\text { students }\end{array}$ & $\begin{array}{l}\text { Percentage } \\
(\%)\end{array}$ \\
\hline $\begin{array}{l}\text { It will help me to be a } \\
\text { successful } \\
\text { professional. }\end{array}$ & 21 & 16.8 \\
\hline $\begin{array}{l}\text { It will help me to increase } \\
\text { my academic performance. }\end{array}$ & 18 & 14.4 \\
\hline $\begin{array}{l}\text { I need it when I travel } \\
\text { abroad. }\end{array}$ & 16 & 12.8 \\
\hline $\begin{array}{l}\text { It is interesting and I enjoy } \\
\text { it. }\end{array}$ & 13 & 10.4 \\
\hline $\begin{array}{l}\text { It will broaden my } \\
\text { knowledge, perspective, and } \\
\text { skills. }\end{array}$ & 13 & 10.4 \\
\hline $\begin{array}{l}\text { I will need it to build } \\
\text { relationship/friendship with } \\
\text { people from the other } \\
\text { country. }\end{array}$ & 9 & 7.2 \\
\hline $\begin{array}{l}\text { I need it to help me to } \\
\text { understand manual. } \\
\text { I need it for my daily }\end{array}$ & 9 & 7.2 \\
\hline $\begin{array}{l}\text { entertainment e.g., reading } \\
\text { English magazine, listening } \\
\text { to music and songs }\end{array}$ & 9 & 7.2 \\
\hline $\begin{array}{l}\text { I am interested in various } \\
\text { English cultures. }\end{array}$ & 6 & 4.8 \\
\hline $\begin{array}{l}\text { I need it for overseas } \\
\text { collaboration } \\
\text { scholarship and trainings. }\end{array}$ & 6 & 4.8 \\
\hline It is compulsory subject. & 3 & 2.4 \\
\hline Total of the students & 125 & 100.00 \\
\hline
\end{tabular}

\section{The Goals of Communication}


Since majority of students decided that speaking or communication skill needs to master in EMP courses, the researcher felt that it is important to know the communication goals of the doctor. The highest number is both to able to speak to the patients and to give presentations chosen equally by 28 students or $22.4 \%$ of the respondents. Giving instruction to the nurses and reporting the diagnose result in English to teamwork were chosen each by 26 students or $20.8 \%$ of the respondents. Only ten students or $8 \%$ of the respondents think speaking is necessary for teamwork discussion. Table 3 summarizesthe students' goals of being able to speak in EMP courses.

Table 3. The goals of communication

\begin{tabular}{lll}
\hline Items & $\begin{array}{l}\text { Import } \\
\text { ant }\end{array}$ & $\begin{array}{l}\text { Percentage } \\
(\%)\end{array}$ \\
\hline $\begin{array}{l}\text { Speaking to the patients } \\
\text { Giving presentations }\end{array}$ & 28 & 22.4 \\
$\begin{array}{l}\text { Giving instruction to the } \\
\text { nurses }\end{array}$ & 26 & 22.4 \\
$\begin{array}{l}\text { Reporting diagnose to } \\
\text { teamwork }\end{array}$ & 26 & 20.8 \\
$\begin{array}{l}\text { Teamwork discussion } \\
\text { Casual conversation }\end{array}$ & 10 & 8 \\
Total of the students & 125 & 5.6 \\
\hline
\end{tabular}

\section{The English Communication Needs}

In order to achieve students' communication needs, the researchers felt necessary to ask students some aspects that the LC UMM or ESP instructors need to improve. Question number 4 in the questionnaires revealed the students' expectations. Majority of the students (35 students or 28\%) expected the teaching delivery should utilize real communication activity. Interesting and authentic materials are expectedby 21 students or $16.8 \%$ as the second option. Slightly higher than having smaller class which was expected20 students or $16 \%$ of the respondents. A complete summary of students' needs of EMP speaking course is presented in the table below.

Table 4. The students' expectations of EMP communication courses

\begin{tabular}{lll}
\hline Items & $\begin{array}{l}\text { Number of } \\
\text { students }\end{array}$ & $\begin{array}{l}\text { Percenta } \\
\text { ge (\%) }\end{array}$ \\
\hline $\begin{array}{l}\text { Using real teaching } \\
\text { delivery activity }\end{array}$ & 35 & 28 \\
$\begin{array}{l}\text { Using interesting and } \\
\text { authentic materials }\end{array}$ & 21 & 16.8 \\
$\begin{array}{l}\text { Having smaller classes } \\
\text { Providing follow-up }\end{array}$ & 20 & 16 \\
$\begin{array}{l}\text { English program } \\
\begin{array}{l}\text { Organizing } \\
\text { proficiency-based class }\end{array}\end{array}$ & 17 & 13.6 \\
$\begin{array}{l}\text { Providing continuous } \\
\text { feedback }\end{array}$ & 15 & 13.6 \\
Total of the students & 125 & 12 \\
\hline
\end{tabular}

In conclusion, communication skill was considered important in EMP course. The medical students realized the importance of doctors' communication in order to enhance better performance in their professional settings. Therefore, the students demanded that EMP course at UMM should use real and authentic activity and materials.

\section{Discussion}


In medical settings at UMM, medical students' expected communicationas the priority to master in order to build the relationship with the patient and colleagues. Doctors who have good English communicationwill affect the competitiveness in healthcare industries. Hence, the doctors need to be preparedwith advanced communication skills inserting into the EMP curriculum. However, at the time of study, the researchers found several critical issues. First, the communication syllabuses for medical students at this university focus on GE and many times teachers didgrammatical correction during communication class. From the table above, it is also revealed that the communication goals that students want to master such as speaking to the patients, giving presentations, and giving instructions to the nurses.

To enhance communication competence, UMM is strongly adopted the model from Shi, Corcos, and Storey, (2001). They conducted research focused-spoken communication for doctors-patients and doctors-to-doctors. Based on the evaluation from the students, the course covered appropriate communication topics for medical students in order to be able to function effectively in their careers. Therefore, the learning process should give the students' chance to speak as well.

The second issue is having 85 students in communication class is considered unusual. Students felt inconvenient with the class atmosphere. Therefore, having smaller classes also need to be taken into account for EMP. Brown \& Lee (2015) stated that the goal of language class is to communicate each other so that the ideal number of students in the classroom should not more than 15 students. Within this number, the teacher will also be at ease in handling the class (Harmer, 2007). Due to big number of students in communication class (80 students), the teacher spent most of the time giving oral explanation. As a result, the students missed the chance to speak.

According to Dudley-Evans and John (1998), teaching ESP should use different methodology from that of General English.In ESP classrooms, activities should similar to what doctors do in their real jobs. For example, the types of communications which are commonly used by doctors in work setting focus on one-to one consultation between doctor and patient. Therefore, ESP teachers are supposed to give a model of communication such way. In addition to teaching delivery, students also expected that the materials should be authentic.According to Antić (2008), good material should be based on various interesting texts and enable the students to implement their knowledge and skills. The materials design should have clear and coherent objectives to help the students achieving the communication goals. Moreover, many researchers suggested that ESP teaching should put the students as close as 
possible to the workplace situation (Holliday, 1995; Mavor \& Trayner, 2001; Svendsen \& Krebs, 1984).

\section{CONCLUSION AND SUGGESTION}

The findings discovered that communication skill was considered important in EMP course. The medical students realized the importance of doctors' communication in order to enhance better performance in their professional settings. ESP teachers are supposed to give a model of communication; Students also expected that the materials should be authentic. The materials design should have clear and coherent objectives to help the students achieving the communication goals. Moreover, students want ESP teaching put them as close as possible to the workplace situation.

The Language Centre can play a crucial role in improving the EMP program at UMM. Especially in syllabuses design the implementation of one-size-fits-all approach need to be reconsidered. This approach has long been discredited by research findings (Long, 2005), but is still practiced in many tertiary institutions including UMM. Language learners have a variety of reasons and learning goals which are shaped by a lot of factors including their previous and present learning experiences. Therefore, this university should consider providing some alternatives to meet the different learning needs and take into account the different past experiences of the students. To create flexibility and to maximize students' learning a variety of goals need to be addressed in the program.

The NA procedure used in this study could help UMM to develop and run appropriate Professional Development (PD) and other professional training useful for developing the teaching capacity of its staff. The findings of the present study suggest that teachers have a need for professional developmentdealing with a large class sizes, managing mixed ability groups. In addition, many teachers believe that learning occurs when both teacher and students meet in the class with teacher directing and explaining everything and students listening and taking notes. However, this belief has been proven ineffective in the students' language acquisition. Designing learner-centered classes, which students have more freedom to decide which speaking materials they need to practice more and which part of communication they need to practice less, look simple in theory but complicated in practice. Professional trainings on learner-centered types and aspects need to be included in teachers' PD.

The EMP teachers need to be provided with wider professional development opportunities and to be encouraged to participate in teaching workshops. Such training should be scheduled and conducted in a continuous manner. From the findings 
of this study, despite their length of service in this institution, it is clear that many teachers are not at the level of teaching competence expected to lift up the doctors' communication competences. Their teaching delivery (including teaching techniques, materials development, and language of instruction) were the main cause of classroom concerns.

The example of syllabus developed from the above NA study (see appendix).

\section{REFERENCES}

Albakrawi, H. T. M. (2013). Needs analysis of the English language secondary hotel students in Jordan. International Journal of English Language Teaching, 1(1), 13-23.

Allwright, R. (1982). Perceiving and pursuing learners' needs. Individualisation.

Oxford:

ModernEnglish Publications.

Antic, Z. (2007). Forward in teaching English for medical purposes. Medicine and Biology, 14(3), 141-147.

Antić, Z. (2008). The new roles of teachers and students in EMP. Medicine and Biology, 15(3), 125-129.

Arani, J. A. (2014). A blended-learning setting in English for medical purposes course incorporating competencies. International Journal of Language and Linguistics, 1(2), 12-16.

Arunanondchai, J., \& Fink, C. (2006). Trade in health services in the ASEAN region. Health Promotion International, 21 Suppl 1(March), 59-66.

https://doi.org/10.1093/heapro/ dal052

Ary, D., Jacobs, L.C., Razavieh, A., Sorensen, C. (2006). Introduction to research in education (7 th ed.). California: Thomson Wadsworth

Atai, M. R., \& Nazari, O. (2011). Exploring reading comprehension needs of Iranian EAP students of health information management (HIM): A triangulated approach. System, 39(1), 30-43. https://doi.org/10.1016/j.system. 2011.01.015

Basturkmen, H. (2010). Developing Courses in English for Specific Purposes. Basingstoke: Palgrave Macmillan.

Brown, H. D., \& Lee, H. (2015). Teaching by principles: An interactive approach to language pedagogy. New York: Pearson Education. Retrieved from https:/ / books.google.co.id/books ?id=4XEbrgEACAAJ

Creswell, J. W. (2012). Qualitative inquiry $\mathcal{E}$ research design: Choosing among five approaches (4th ed.). Thousand Oaks, CA: Sage. 
Dörnyei, Z. (2002). Questionnaires in second language research: Construction, administration, and processing. Taylor \& Francis. Retrieved from https://books.google.co.id/books ?id=B8bnlCNVPowC

Dudley-Evans, T., \& John, M. J. S. (1998). Developments in English for specific purposes: A multi-disciplinary approach. Cambridge University Press. Retrieved from https://books.google.co.id/books ?id=RvYcuq8QrjAC

Fahad, A., \& Alfehaid, T. (2011). Developing an ESP curriculum for students of health sciences through needs analysis and course evaluation in Saudi Arabia. University of Leceister.

Faraj, B. M. A. (2015). English for medical education in EFL context. Journal of Teaching English for Specific and Academic Purposes, 3(1), 121-148.

Farida, D., \& Asmaa, B. (2017). The role of ESP in economic sciences and technology. Novelty Journals, 4(1), 13-19.

Ghenghesh, P. (2013). Students and teachers of engineering speak out! What do you really need? Arab World English Journal, Volume.4 N(1), 11-27.

Gözüyeşil, E. (2014). An analysis of engineering students' English language needs. Procedia - Social and Behavioral Sciences, 116, 4182-4186.

https://doi.org/10.1016/j.sbspro. 2014.01.913

Grier, A. S. (2005). Integrating needs assessment into career and technical curriculum development. Journal of Industrial Teacher Education, 42(1), 59-66.

Habbash, M. M., \& Albakrawi, H. T. (2014). Needs analysis of engineering students ' English needs at the University of Tabuk. Journal of Education and Practice, 5(38), 68-75.

Harmer, J. (2007). How to teach English. Essex: Pearson Education Limited. https://doi.org/10356/15300

Ho, B. (2014). Communicating in English during computer science internships. International Journal of Humanities and Social Science, 4(7), 314-330.

Holliday, A. (1995). Assessing language needs within an institutional context: An ethnographic approach. English for Specific Purposes, 14(2), 115-126. https://doi.org/10.1016/0889-490 6(95)00006-D

Holliday, A., \& Cooke, T. (1982). An ecological approach to ESP. Lancaster Practical Papers in English Language Education, 5, 123-143.

Hutchinson, T., \& Waters, A. (1987). English for specific purposes: A learning-centered approach. 
Glasgow: Cambridge University Press.

https://doi.org/10.1016/0346-251 X(87)90056-X

Ibrahim, A. (2016). ESP needs analysis: A case study of PEH students, University of Khartoum. Sino-US English Teaching, 13(12), 905-923. https://doi.org/10.17265/1539-80 72/2016.12.001

Jeczelewski, S. (2016). Needs analysis, course design and evaluation of business English. University of Iceland.

Juan, L. I. (2014). Needs analysis of business English graduates: A case study of Shandong. CSCanada, 6(3), 111-117.

https://doi.org/10.3968/4712

Kim, H. H. (2013). Needs analysis for english for specific purpose course development for engineering students in Korea. International Journal of Multimedia and Ubiquitous Engineering, 8(6), 279-288.

https://doi.org/10.14257/ijmue.2 013.8.6.28

Lin, C. H., Wu, W. C., \& Huang, Y. T. (2013). English for specific purposes (ESP) for hospitality college students and hotel employees in Taiwan. International Journal of Education and Research, 1(8), 1-14.
Long, M. H. (2005). Second language needs analysis. Cambridge: Cambridge University Press.

Maclean, J., Betancourt, Z. S., \& Hunter, A. (2000). The evolution of an ESP programme in Cuba. English for Specific Purposes, 19(1), 17-30. Retrieved from http://www.scopus.com/inward / record.url?eid=2-s2.0-0039331039 \&partnerID $=40 \& m d 5=76706 f 129 b$ 2a2588d93d9b3008b1a9f5

Mavor, S., \& Trayner, B. (2001). Aligning genre and practice with learning in Higher Education: An interdisciplinary perspective for course design and teaching. English for Specific Purposes, 20(4), 345-366.

https://doi.org/10.1016/S0889-49 06(01)00025-4

Milosavljević, N., Vuletić, A., \& Jovković, L. (2015). Learning medical English: A prerequisite for successful academic and professional education. Srpski Arhiv Za Celokupno Lekarstoo, 143(3-4), 237-240. https://doi.org/10.2298/SARH15 04237M

Morreale, S. P., \& Pearson, J. C. (2008). Why communication education is important: The centrality of the discipline in the 21st century. Communication Education, 57(2), 224-240.

https://doi.org/10.1080/0363452

0701861713 
Mubaraq, Y. F. (2017). Needs analysis: Medical English for Indonesian medical students. In National Seminar Proceeding (pp. 568-575). Banjarmasin.

Munby, J. (1978). Communicative syllabus design: A sociolinguistic model for defining the content of purpose-specific language programs. Cambridge: Cambridge University Press.

Noori, M., \& Mazdayasna, G. (2014). A triangulated study of target situation needs of Iranian undergraduate students of English language and literature. Proceedings of the International Conference on Current Trends in ELT, 98, 1374-1379. https://doi.org/10.1016/j.sbspro. 2014.03.555

Pavel, E. (2014). Teaching English for medical purposes. Bulettin of the Transilvania, 7(2), 39-46.

Poedjiastutie, D., \& Oliver, R. (2017). Exploring students' learning needs: Expectation and challenges. English Language Teaching, 10(10), 124.

https://doi.org/10.5539/elt.v10n 10p124

Polyakova, T. (2015). Variety of engineers' needs in the foreign language usage as a basis for their training diversification. Procedia Social and Behavioral Sciences, 214(June),

86-94. https://doi.org/10.1016/j.sbspro. 2015.11.598

Prachanant, N. (2012). Needs analysis on English language use in tourism industry. Procedia - Social and Behavioral Sciences, 66, 117-125. https://doi.org/10.1016/j.sbspro. 2012.11.253

Punch, K. F. (1998). Introduction to Social Research: Quantitative and Qualitative Approaches (1st ed.). London, Thousand Oaks California, New Delhi: SAGE Publications.

Richards, J. C. (2001). Curriculum development in language teaching. Edinburgh: Cambridge University Press.

Richterich, R., \& Chancerel, J. L. (1980). Identifying the Needs of Adults Learning a Foreign Language. Pergamon Press. Retrieved from https://books.google.co.id/books $? \mathrm{id}=4$ SENAQAAIAAJ

Robinson, P. C. (1991). ESP today: a practitioner's guide. New York: Prentice Hall.

So'ud, M.-D. N. (2016). Evaluation of ESP course designed to first year, Sudanese law students, Alneelain University from the students' perspective. Journal of Humanities, $\begin{array}{llll}\text { Vol } & .17 & \text {.(1), } & 11 .\end{array}$ https://doi.org/10.1101/112268

Songhori, M. H. (2008). Introduction to needs analysis. English for Specific Purposes, $4(4)$, $1-25$. 
https://doi.org/10.2478/slgr-201 4-0031

Supakankunti, S., \& Herberholz, C. (2012). Transforming the ASEAN Economic Community (AEC) into a global services hub: Enhancing the competitiveness of the jealth services sector in Thailand. Developing ASEAN Economic Community (AEC) into A Global Services Hub, (March), 147-171.

Svendsen, C., \& Krebs, K. (1984). Identifying english for the job: Examples from health care occupations. The ESP Journal, 3(2), 153-164.

https://doi.org/10.1016/0272-238 0(84)90026-X

Tsou, W. (2009). Needs-based curriculum development: A case study of NCKU's ESP program. Taiwan International ESP Journal, 1(1), 77-95.
Unueshotse, B. F. (2017). Needs analysis of the writing skills of HND Business Studies students at Auchi Polytechnic, Auchi Edo State. International Journal of English and Literature, 8(6), 74-87. https://doi.org/10.5897/IJEL2017 .1040

West, R. (1994). Needs analysis in language teaching. Language Teaching, 27(1), 1-19. https://doi.org/10.1017/S026144 4800007527

Zhang, Z., \& Wang, Y.-X. J. (2015). English language usage pattern in China mainland doctors: AME survey-001 initial analysis results. Quantitative Imaging in Medicine and Surgery, 5(1), 174-181. https://doi.org/10.3978/j.issn.222 3-4292.2014.12.05. 